\title{
The Use of ACE inhibitor/ARB in SARS-CoV-2 Patients: A Comprehensive Narrative Review
}

\author{
Timotius Ivan Hariyanto', Karunia Valeriani Japar', Vika Damay', Felix Kwenandar', \\ Novia Lauren Sieto ${ }^{1,2}$, Andree Kurniawan ${ }^{3}$ \\ ${ }^{1}$ Medical Doctor, Faculty of Medicine, Pelita Harapan University, Boulevard Jendral Sudirman street, Karawaci, \\ Tangerang, Indonesia 15811, ${ }^{2}$ Medical Doctor, Mochtar Riady Institute of Nanotechnology, Boulevard Jendral Sudirman \\ street, Karawaci, Tangerang, Indonesia 15811, ${ }^{3}$ Medical Doctor, Internal Medicine Specialist, Department of Internal \\ Medicine, Faculty of Medicine, Pelita Harapan University, Boulevard Jendral Sudirman street, Karawaci, Tangerang, \\ Indonesia 15811
}

The three most common comorbidities that are associated with increased mortality in COVID-19 patients are Hypertension, Diabetes, and Cardiovascular disease, Angiotensinconverting enzyme (ACE) inhibitors and Angiotensin II receptor blockers (ARB) are the drugs most commonly prescribed for the management of these diseases. Recent experimental study in animals and humans have found that SARS-CoV-2 uses ACE2 as the receptors for entry. Moreover, in an animal study, the use of ACE inhibitor/ARB increases the level of ACE2 expression that can lead to increased SARS-CoV-2 infectivity. On the other side, some evidences suggest that the ACE2 receptor is not necessary for SARS-CoV-2 entry into the cell and suggested that there is a cofactor that play part. Experimental studies in humans also showed that there is no association between ACE inhibitor/ARB with SARSCoV-2 infectivity and mortality. In conclusion, there is still insufficient data to stop the use of inhibitor/ARB in SARS-CoV-2 patients. Therefore, we suggested that in line with the recommendations from ESC and AHA/ACC, the use of these two drugs in SARS-CoV-2 patients with cardiovascular comorbidity should still be continued.

Key words: COVID-19; SARS-CoV-2; ACE2; ACE inhibitors; Angiotensin II

\section{Access this article online}

Website:

http://nepjol.info/index.php/AJMS DOI: 10.3126/ajms.v11i6.29911

E-ISSN: 2091-0576

P-ISSN: $2467-9100$

Copyright (c) 2020 Asian Journal of Medical Sciences

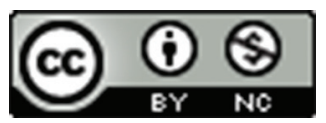

This work is licensed under a Creative Commons Attribution-NonCommercial 4.0 International License.

\section{INTRODUCTION}

There are three highly pathogenic human coronaviruses $(\mathrm{CoVs})$ that have been identified so far, including Middle East respiratory syndrome coronavirus (MERS-CoV), severe acute respiratory syndrome (SARS) coronavirus (SARS-CoV), and a 2019 novel coronavirus (2019-nCoV), more recently known as SARS-CoV-2. ${ }^{1}$ Among them, the firstly reported was SARS-CoV in Guangdong, China in 2002. ${ }^{2}$ SARS-CoV caused human-to-human transmission and resulted in the 2003 outbreak with about $10 \%$ case fatality rate (CFR), ${ }^{3}$ while MERS-CoV was reported in Saudi Arabia in June $2012{ }^{4}$ with the limited human-tohuman transmission but showed a higher mortality rate with CFR of about $37.1 \% .^{5}$ The $2019-\mathrm{nCoV}$ was first reported in Wuhan, China in December 2019 with patients diagnosed with an atypical type of pneumonia. ${ }^{6}$ The rate of transmission of SARS-COV2 among humans has exceeded both SARS-CoV and MERS-CoV, affecting more than 200 countries around the world. ${ }^{7}$

The number of COVID-19 cases have reached to more than 7 million confirmed positive cases with a reported death toll of more than 4 lakh patients. ${ }^{7}$ According to the study on 1099 COVID-19 patients in China, the most common comorbidity was hypertension (15\%) followed by diabetes $(7.4 \%)$, and cardiovascular disease $(2.5 \%)$. These comorbidities were associated with more severe clinical presentation and poor outcomes. The prevalence of these comorbidities was increased to up to three times 
higher in patients with severe diseases as compared to those with non-severe diseases. ${ }^{8}$ Another study from China that assessed 140 patients with COVID-19 also reported that hypertension and diabetes were the most common comorbidities among the patients with the prevalence up to $30 \%$ and $12 \%$ respectively. ${ }^{9}$ Notably, the most frequent comorbidities reported in these two studies are treated with angiotensin-converting enzyme (ACE) inhibitors or angiotensin II receptor blockers (ARB) because of efficacy and wide coverage; . This study aims to review the current evidence regarding the role of ACE2 inthe pathogenesis of COVID-19 and the safe usage of ACE inhibitor/ARB in COVID-19 patients.

\section{MATERIALS AND METHODS}

Our literature search strategy involved searching for articles on PubMed and Google Scholar using the search terms "COVID-19 and ACE2", "COVID-19 and ACE inhibitor", "COVID-19 and ARB", "coronavirus and ACE2", "coronavirus and ACE inhibitor", and "coronavirus and ARB". Articles analyzing the role of ACE inhibitor/ARB in SARS-CoV-2 patients published in the year of 2020 were selected. Additional literature cited in the selected articles encompassing the topic of interest was also considered.

\section{POTENTIAL RISKOF ACE INHIBITOR/ARB AMONGSARS-COV-2PATIENTS}

There are many similarities of SARS-CoV-2 with the original SARS-CoV. Using computer modeling, Xu et al. ${ }^{10}$ found that the spike (S) proteins of SARS-CoV-2 and SARS-CoV have almost identical 3-D structures in the receptor-binding domain that maintains van der Waals forces. SARS-CoV-2 and SARS-CoV spike (S) proteins share $76.5 \%$ identity in amino acid sequences. The phylogenetically related coronaviruses' $S$ protein anchors the exterior surface of these viruses to ACE2 receptors which serve as their binding sites in the lower respiratory tract of infected patients to gain entry into the lungs, resulting into viral pneumonia and potentially fatal respiratory failure in susceptible persons after 10-14 days. ${ }^{10}$ Another similarity was shown by Hoffman et al. ${ }^{11}$ that employed VZV pseudotypes bearing $S$ protein to study cell entry of SARS and SARS-CoV-2. Both S proteins SARS$2-S$ and SARS-S were robustly incorporated into VZV particles. Moreover, SARS-2-S entered into an spectrum of cell lines similar to SARS-S, suggesting the similarities in the entry receptor. ${ }^{11}$ From the study that was done in 2003 by Li et al, ${ }^{12}$ it was found that SARS-CoV engages angiotensin-converting enzyme 2 (ACE2) as the entry receptor. So, there is a possibility that SARS-CoV-2 also uses ACE2 as an entry receptor to host cells.

Using normal lung tissue from eight adult donors, Zhao et al. ${ }^{13}$ demonstrated that $83 \%$ of ACE2-expressing cells were alveolar epithelial type II cells, suggesting that these cells can serve as a reservoir for viral invasion. Sequence analysis from the experimental study by Hoffman et al. ${ }^{11}$ that was done in 2020 revealed that SARS-CoV-2 clusters with SARS-CoV-related viruses from bats (SARSr-CoV), of which some but not all can use ACE2 for host cell entry. Analysis of the receptor-binding motif (RBM), a portion of the receptor-binding domain (RBD) that makes contact with ACE2, revealed that most amino acid residues essential for ACE2 binding by SARS-S were conserved in SARS-2-S. ${ }^{11}$ Moreover, anti-serum raised against human ACE2 blocked SARS-S and SARS-2-S driven entry. Finally, authentic SARS-CoV-2 infected BHK-21 cells transfected to express ACE2 cells but not parental BHK-21 cells with high efficiency, indicating that SARS-2-S, like SARS-S, uses ACE2 for cellular entry. ${ }^{11}$ Zhuo et al. ${ }^{14}$ also demonstrated that overexpressing ACE2 from different species in HeLa cells with human ACE2, pig ACE2, civet ACE2 allowed SARS$\mathrm{CoV}-2$ infection and replication, thereby directly showing that SARS-CoV-2 uses ACE2 as a cellular entry receptor. ${ }^{14,15}$

Expression of the ACE2 receptor is also found in many extrapulmonary tissues including heart, kidney, endothelium, and intestine. ${ }^{16-18}$ Importantly, ACE2 is highly expressed on the luminal surface of intestinal epithelial cells, functioning as a co-receptor for nutrient uptake, in particular for amino acid resorption from food, therefore Hashimoto et al. ${ }^{19}$ predict that the intestine might also be a major entry site for SARS-CoV-2 and that the infection might have been initiated by eating food from the Wuhan market, the putative site of the outbreak. ${ }^{19}$ Recent bioinformatics analysis on available single-cell transcriptomes data of normal human lung and gastrointestinal system revealed that ACE2 was also expressed in esophagus upper and stratified epithelial cells and absorptive enterocytes from ileum and colon. ${ }^{20}$ Patients with positive COVID-19 infection that come to the hospitals often have gastrointestinal symptoms like nausea, vomiting, or diarrhea as one of their major complaints. Report from 1099 patients with laboratory-confirmed COVID-19 in Wuhan, China found that gastrointestinal complaints comprise about $8.8 \%$ of all signs and symptoms. ${ }^{8} \mathrm{~A}$ similar report that assesses clinical characteristics from 140 patients with positive COVID-19 results also found that up to $39.6 \%$ of patients have gastrointestinal symptoms at hospital admission. ${ }^{9}$ Notably, the first case of $2019-\mathrm{nCoV}$ infection confirmed in the United States reported a 2-day history of nausea and vomiting on admission, and then passed a loose bowel movement on hospital day 2 . The viral 
nucleic acids of loose stool and both respiratory specimens later tested positive. ${ }^{21}$ All these data and findings suggest that SARS-CoV-2 may also use ACE2 as their receptor to entry target host cells.

In the Renin-Angiotensin-Aldosterone System (RAAS), ACE2 catalyzes the conversion of angiotensin II to angiotensin $1-7$, which acts as a vasodilator and exerts protective effects in the cardiovascular system. A study was done by Ferrario et al. ${ }^{22}$ explained that intravenous infusions of ACEIs and ARBs in experimental animals increase the numbers of angiotensin-converting enzyme 2 (ACE2) receptors in the cardiopulmonary circulation. It showed that cardiac ACE2 mRNA increased by 4.7fold or 2.8-fold in rats medicated with either lisinopril or losartan, respectively, so that inhibition of Ang II increases cardiac ACE2 gene transcription. Twelve-day administration of agents that either inhibit the synthesis of circulating Ang II or block the activity of Ang II at the AT1 receptor-induced an increase in cardiac ACE2 mRNA, accompanied by significant increases in cardiac membrane ACE2 activity in rats medicated with either losartan or both losartan and lisinopril. ${ }^{22}$ This suggested that patients taking ACEIs or ARBs chronically for cardiovascular diseases are assumed to have increased numbers of ACE2 receptors throughout their cardiopulmonary circulations as observed in experimental animal models. ${ }^{22}$ Another study was done by Furuhashi et al. ${ }^{23}$ which showed that urinary ACE2 level was increased in hypertensive patients treated with olmesartan. Angiotensin-converting enzyme-1 (ACE-1) and angiotensin-converting enzyme-2 (ACE-2) both played a role in the modulation of ARDS in COVID-19 patients. ACE-1 catalyzes angiotensin I into angiotensin II, which causes vasoconstrition, bronchoconstriction, increases vascular permeability, inflammation, fibrosis and thereby promotes the development of ARDS and lung failure in patients infected with the SARS-CoV and SARS-CoV-2. ${ }^{24,25}$ Figure 1 summarizes the interaction between SARS-CoV-2 and the Renin-Angiotensin-Aldosterone System. ${ }^{26}$

The study conducted by Guo T et al. in 187 COVID-19 patients showed elevated TnT levels in patients on angiotensin-converting enzyme inhibitors (ACEIs)/ angiotensin receptor blockers (ARBs) $(11 / 19$ [21.1\%] vs 8/19 [5.9\%]). Patients with ACE inhibitor/ARB usage also had a higher mortality rate when compared to the patients not on treatment with these drugs (36.8\% vs $21.4 \%$ respectively, $\mathrm{p}=0.13) .{ }^{27}$ From this data, it can be concluded that the use of ACE inhibitors (ACEi) or Angiotensin II receptor blockers (ARB) drugs is associated with increased ACE2 expression and can potentially increase COVID-19 infectivity. Table 1 summarize the evidence that support the harm of ACE inhibitor/ARB.

\section{EVIDENCE THAT SHOWEDTHE SAFETYOF ACE INHIBITOR/ARB}

Sama IE et al. ${ }^{28}$ found that the use of neither an ACE inhibitor nor an ARB is associated with higher plasma

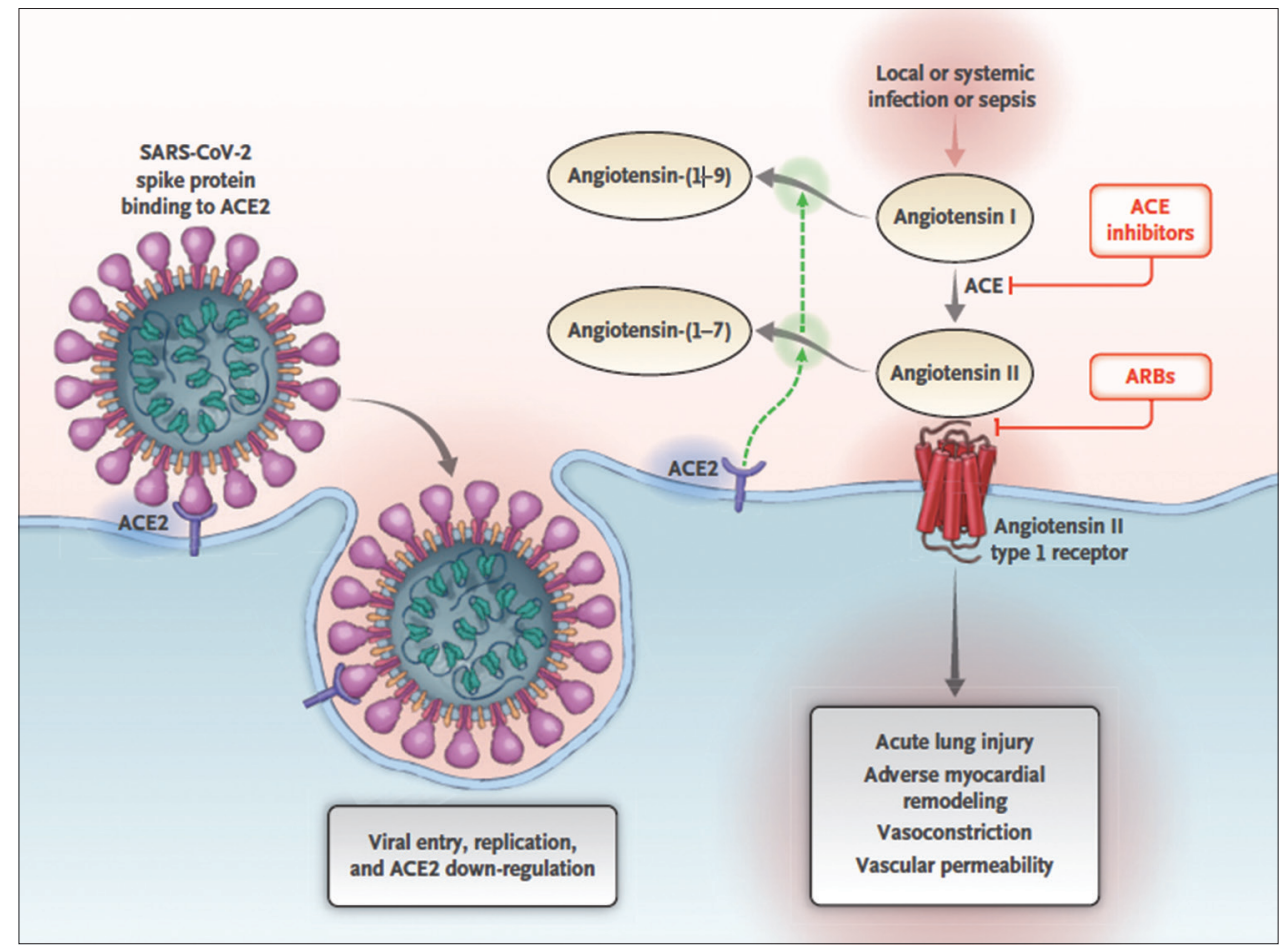

Figure 1: Interaction between SARS-CoV-2 and the Renin-Angiotensin-Aldosterone system ${ }^{26}$ 


\begin{tabular}{|c|c|c|}
\hline Study & Results & Arguments \\
\hline Xu et al. ${ }^{10}$ & $\begin{array}{l}\text { SARS-CoV-2 and SARS-CoV have almost identical 3-D structures of } \\
\text { spike (S) protein in the receptor-binding domain and share } 76.5 \% \text { identity } \\
\text { in amino acid sequences }\end{array}$ & \\
\hline \multirow{3}{*}{ Hoffman et al. ${ }^{11}$} & SARS-CoV-2 and SARS-CoV have similarities in the choice of entry receptor & \\
\hline & $\begin{array}{l}\text { Anti-serum against human ACE2 blocked SARS-S and SARS-2-S driven } \\
\text { entry }\end{array}$ & $\begin{array}{l}\text { SARS-CoV-2 also uses ACE2 as their } \\
\text { entry receptor }\end{array}$ \\
\hline & $\begin{array}{l}\text { SARS-CoV-2 infected BHK-21 cells transfected to express ACE2 cells, } \\
\text { indicating that SARS-2-S uses ACE2 for cellular entry }\end{array}$ & \\
\hline Li et al. ${ }^{12}$ & $\begin{array}{l}\text { SARS-CoV used angiotensin-converting enzyme } 2 \text { (ACE2) as their entry } \\
\text { receptor }\end{array}$ & \\
\hline Zhao et al. ${ }^{13}$ & $83 \%$ of ACE2-expressing cells were alveolar epithelial type II cells & \\
\hline Zhuo et al. ${ }^{14}$ & $\begin{array}{l}\text { Overexpressing ACE2 from different species in HeLa cells with human } \\
\text { ACE2, pig ACE2, civet ACE2 allowed SARS-CoV-2 infection and } \\
\text { replication }\end{array}$ & \\
\hline Hashimoto et al. ${ }^{19}$ & $\begin{array}{l}\text { ACE2 is highly expressed on the luminal surface of intestinal epithelial } \\
\text { cells, therefore intestine might also be a major entry site for SARS-CoV-2 }\end{array}$ & \\
\hline Guan et al. ${ }^{8}$ & $\begin{array}{l}\text { Gastrointestinal complaints comprise about } 8,8 \% \text { of all signs and } \\
\text { symptoms of COVID- } 19\end{array}$ & \\
\hline Zhang et al. ${ }^{15}$ & $\begin{array}{l}\text { Up to } 39.6 \% \text { of patients have gastrointestinal symptoms at hospital } \\
\text { admission }\end{array}$ & \\
\hline Holshue et al. ${ }^{21}$ & $\begin{array}{l}\text { Confirmed COVID-19 case passed a loose bowel movement on hospital } \\
\text { day } 2 \text { and viral nucleic acids of loose stool tested positive }\end{array}$ & \\
\hline Ferrario et al. ${ }^{22}$ & $\begin{array}{l}\text { Cardiac ACE2 mRNA increased by } 4.7 \text {-fold or } 2.8 \text {-fold in rats medicated } \\
\text { with either lisinopril or losartan, respectively }\end{array}$ & $\begin{array}{l}\text { The use of ACE inhibitor/ARB increases } \\
\text { the level of ACE2 expression }\end{array}$ \\
\hline Furuhashi et al. ${ }^{23}$ & $\begin{array}{l}\text { ACE2 level was increased in hypertensive patients treated with } \\
\text { Olmesartan }\end{array}$ & \\
\hline Guo et al. ${ }^{27}$ & $\begin{array}{l}\text { In } 187 \text { patients with confirmed COVID-19, patients with ACE inhibitor/ } \\
\text { ARB usage had a higher mortality rate when compared without the use of } \\
\text { these two drugs }\end{array}$ & $\begin{array}{l}\text { The use of ACE inhibitor/ARB will } \\
\text { increase the level of ACE2 expression, } \\
\text { therefore facilitating SARS-CoV-2 } \\
\text { entry into a host cell and causing an } \\
\text { increased risk of mortality }\end{array}$ \\
\hline
\end{tabular}

ACE2 concentrations. In a study performed by Campbell DJ et al. ${ }^{29}$ the intravenous administration of ACE inhibitors in patients with coronary artery disease did not influence angiotensin-(1-7) production, a finding that calls into question whether ACE inhibitors have any direct effects on ACE2-directed angiotensin II metabolism. Similarly, in another study, among patients with hypertension, angiotensin-(1-7) levels appeared to be unaffected after initial treatment with the ACE inhibitor captopril; however, with exposure to captopril monotherapy over a period of 6 months, angiotensin-(1-7) levels increased. ${ }^{30}$ These findings contradict the previous belief in which ACE inhibitors and ARB drugs were labeled as probable 'ACE-2-increasing drugs' $^{31}$

Moreover, currently, no data proves the direct causal relationship between ACE2 activity and the mortality caused by SARS-CoV-2. Hamming et al. ${ }^{18}$ in his study found that the abundant expression of ACE2 in endothelial cells and smooth muscle cells of several visceral organs is discordant with the absence of the virus in these organs. In addition, only one of seven ACE2-expressing intestinal cell lines seemed to be susceptible to SARS-CoV infection in vitro. ${ }^{32}$ At the same time, however, the lack of ACE2 expression in immune cells, colonic epithelial cells, and in neuronal cells of the brain contrasts with the confirmed infection of such cells. These contradictions suggest that other receptors, co-receptors, or mechanisms may be involved in the interaction between the virus and its target cells. ${ }^{17,18}$ The experimental study that was done by Imai et al. ${ }^{33}$ in 2005 showed that ACE2 and AT2-receptors play protective roles in severe acute lung injury, whereas ACE, angiotensin II, and AT1-receptors probably induce lung failure. It also showed by another similar study that SARS-CoV or its spike protein down-regulates ACE2 expression resulting in a diminished protective role of ACE2 and more severe lung injury in mice could be attenuated by administration of ARB. Therefore, the protective role of ARB is suggested in SARS-CoV associated lung injury and gives rise to the hypothesis that rather than its inhibition, the primary activation of RAAS in cardiovascular patients is the reason they are more prone to a deleterious outcome. ${ }^{34,35} \mathrm{In}$ his study that showed increased mortality among COVID-19 positive patients with comorbidity hypertension, diabetes, or cardiovascular disease, Guan et al. ${ }^{8}$ do not report the number of patients taking ACE inhibitors or ARB.

A research conducted by de Abajo FJ et al. ${ }^{36}$ upon 1139 cases and 11390 population controls found that compared with users of other antihypertensive 
drugs, users of RAAS inhibitors had no increased risk for COVID-19 requiring admission to hospital. (OR 0.94; 95\% CI 0.77-1.15). No increased risk was observed with either angiotensin-converting enzyme inhibitors (adjusted OR 0.80, 0.64-1.00) or angiotensin-receptor blockers $(1 \cdot 10,0 \cdot 88-1 \cdot 37)$. Sex, age, and background cardiovascular risk did not modify the adjusted OR between the use of RAAS inhibitors and COVID-19 requiring admission to the hospital. ${ }^{36}$ Another study conducted by Mehta et al. ${ }^{37}$ also found no association between ACEI or ARB use and COVID-19 test positivity. The overlap propensity score weighting showed no significant association of ACEI and/or ARB use with COVID-19 test positivity (overlap propensity score-weighted odds ratio, 0.97; $95 \%$ CI, 0.81-1.15). In terms of mortality, the use of ACE inhibitors/ARB may even decrease the mortality rate. In a retrospect, a multicentered study of 1128 with hypertension diagnosed with COVID-19, found that inpatient use of ACEI/ARB was associated with a lower risk of all-cause mortality compared with ACEI/ ARB nonusers. ${ }^{38}$ For that reason, based on currently available data and statistics, the hypothesis of a causal relationship between ACE inhibitors or ARB intake and severe outcome of SARS-CoV-2 is not legitimate. ${ }^{39}$ Table 2 summarize the evidence supporting the safety of ACE inhibitor/ARB.

\section{WHAT SHOULD PHYSICIANS DO}

Given the conflicting evidence regarding the use of ACE inhibitor/ARB in SARS-CoV-2, many physicians have been confused about whether to continue or to defer the use of these two drugs in COVID-19 patients. But, if we look closely into the evidence that stated the harms of ACE inhibitor/ARB in SARS-CoV-2 patients, most of the arguments were just based on the hypothesis. Most of the evidence was also conducted in animals that can have different results when it is applied to humans. Besides, there is abundant and solid evidence of the mortality-lowering effects of RAAS inhibitors in cardiovascular disease. ACE inhibitors and ARB are the cornerstone of a prognostically beneficial heart failure therapy with the highest level of evidence with regard to mortality reduction..$^{40}$ Similarly, ACE inhibitor, Angiotensin II-Receptor Blocker, and Mineralocorticoid Receptor Antagonist are part of the standard therapy in hypertension ${ }^{41}$ and post myocardial infarction. ${ }^{42} \mathrm{~A}$ significant reduction of post-infarct mortality was observed with the administration of either of these three drugs classes. ${ }^{42}$ Therefore, based on all this data, European Society of Cardiology (ESC) ${ }^{39,43}$ and American College of Cardiology/American Heart Association $(\mathrm{AHA})^{44}$ does not recommend the discontinuation of ACE inhibitors or ARB therapy in patients with heart failure, hypertension, or myocardial infarction who are also suffering from SARS-CoV-2 infection. Moreover, ACE2 whose expression is enhanced with an ACE inhibitor or ARB therapy has the ability to suppress inflammation and has been suggested as a potential new therapy for inflammatory lung diseases, cancer, diabetes, and hypertension. ${ }^{45}$ Given the fact that no current evidence that proves a direct causal relationship between the use of ACE inhibitor/ARB and COVID-19 infectivity or mortality and the facts that ACE inhibitors/ARB have many benefits in cardiovascular disease, we suggest following the recommendation from ESC and ACC/AHA to continue the use of ACE inhibitor/ARB in SARS-CoV-2 patients that have cardiovascular comorbidities.

Table 2: Summary of evidence supporting the safety of ACE inhibitor/ARB

\begin{tabular}{|c|c|c|}
\hline Study & Results & Arguments \\
\hline Sama et al..$^{28}$ & $\begin{array}{l}\text { Neither ACE inhibitor nor ARB was associated with higher plasma ACE2 } \\
\text { concentrations }\end{array}$ & \multirow{3}{*}{$\begin{array}{l}\text { The use of ACE inhibitor/ARB was } \\
\text { not associated with higher ACE2 } \\
\text { levels }\end{array}$} \\
\hline Campbell et al. ${ }^{29}$ & $\begin{array}{l}\text { Intravenous administration of ACE inhibitors in patients with coronary artery } \\
\text { disease did not influence angiotensin-(1-7) production }\end{array}$ & \\
\hline Luqueet al. ${ }^{30}$ & $\begin{array}{l}\text { Among patients with hypertension, angiotensin-(1-7) levels were unaffected } \\
\text { after initial treatment with ACE inhibitor captopril }\end{array}$ & \\
\hline Hamming et al. ${ }^{18}$ & $\begin{array}{l}\text { Abundant expression of ACE2 in endothelial cells and smooth muscle cells of } \\
\text { several visceral organs but the absence of virus in these organs }\end{array}$ & \multirow{4}{*}{$\begin{array}{l}\text { Other receptors or co-receptors or } \\
\text { mechanisms may be involved in the } \\
\text { interaction between SARS-CoV-2 } \\
\text { and its target cells } \\
\text { ACE2 may play a protective role }\end{array}$} \\
\hline Chan et al. ${ }^{32}$ & $\begin{array}{l}\text { Only one of seven ACE2-expressing intestinal cell lines were susceptible to } \\
\text { SARS-CoV infection in vitro }\end{array}$ & \\
\hline Imai et al. ${ }^{33}$ & ACE2 and AT2-receptors play protective roles in severe acute lung injury & \\
\hline Kuba et al. ${ }^{34}$ & $\begin{array}{l}\text { Downregulation of ACE2 expression by SARS-CoV resulted in more severe } \\
\text { lung injury in mice }\end{array}$ & \\
\hline de Abajo et al. ${ }^{36}$ & $\begin{array}{l}\text { Users of RAAS inhibitors had no increased risk for COVID-19 requiring } \\
\text { hospital admission (OR } 0.94 ; 95 \% \mathrm{CI} 0.7701 .15)\end{array}$ & \multirow{3}{*}{$\begin{array}{l}\text { The use of ACE inhibitor/ARB was } \\
\text { not associated with the increased } \\
\text { risk of COVID-19 infections, and } \\
\text { even was associated with a lower } \\
\text { risk of mortality }\end{array}$} \\
\hline Mehta et al. ${ }^{37}$ & $\begin{array}{l}\text { No association between ACE inhibitor/ARB use and COVID-19 test positivity } \\
\text { (OR } 0.97 ; 95 \% \mathrm{Cl} 0.81-1.15 \text { ) }\end{array}$ & \\
\hline Zhang et al. ${ }^{38}$ & $\begin{array}{l}\text { Inpatient use of ACE inhibitor/ARB was associated with a lower risk of all- } \\
\text { cause mortality from COVID-19 compared with ACE inhibitor/ARB nonusers. }\end{array}$ & \\
\hline
\end{tabular}




\section{CONCLUSION}

Finally, a more comprehensive or randomized clinical trial study is needed to prove the direct causal relationship between the use of ACE inhibitors or ARB and SARSCoV-2 infectivity or mortality. Until then, the use of ACE inhibitor/ARB in SARS-CoV-2 patients with cardiovascular comorbidity should still be continued.

\section{AUTHORSHIP}

All authors whose names appear on the submission:

1. made substantial contributions to the conception or design of the work; or the acquisition, analysis, or interpretation of data; or the creation of new software used in the work;

2. drafted the work or revised it critically for important intellectual content;

3. approved the version to be published; and

4. agree to be accountable for all aspects of the work in ensuring that questions related to the accuracy or integrity of any part of the work are appropriately investigated and resolved.

\section{ABBREVIATIONS}

SARS-CoV-2: Severe Acute Respiratory Syndrome Coronavirus 2

ACE: Angiotensin-Converting Enzyme

ARB: Angiotensin II Receptor Blocker

MERS-CoV: Middle East Respiratory Syndrome Coronavirus

RBM: Receptor Binding Motif

RBD: Receptor Binding Domain

AT-II: Angiotensin II

RAAS: Renin-Angiotensin-Aldosterone System

ACC: American College of Cardiology

ESC: European Society of Cardiology

\section{REFERENCE}

1. Wang N, Shang J, Jiang S and Du L. Subunit Vaccines Against Emerging Pathogenic Human Coronaviruses. Frontiers in Microbiology. 2020;11:181.

https://doi.org/10.3389/fmicb.2020.00298

2. Zhong NS, Zheng BJ, Li YM, Poon, Xie ZH, Chan KH, et al. Epidemiology and cause of severe acute respiratory syndrome (SARS) in Guangdong, People's Republic of China, in February 2003. Lancet. 2003;362:1353-1358.

https://doi.org/10.1016/S0140-6736(03)14630-2

3. Du L, He Y, Zhou Y, Liu S, Zheng BJ and Jiang S. The spike protein of SARS-CoV-a target for vaccine and therapeutic development. Nat Rev Microbiol. 2009;7:226-236.

https://doi.org/10.1038/nrmicro2090

4. Zaki AM, van Boheemen S, Bestebroer TM, Osterhaus ADME and
Fouchier RAM. Isolation of a novel coronavirus from a man with pneumonia in Saudi Arabia. N Engl J Med. 2012;367:1814-1820. https://doi.org/10.1056/NEJMoa1211721

5. World Health Organization. Middle East Respiratory Syndrome (MERS) situation update, January 2020.

http://www.emro.who.int/pandemic-epidemic-diseases/merscov/mers-situation-update-january-2020.html

6. Zhu N, Zhang D, Wang W, Li X, Yang B, Song J, et al. A novel coronavirus from patients with pneumonia in China, 2019. N. Engl. J. Med. 2020;382:727-733.

https://doi.org/10.1056/NEJMoa2001017

7. World Health Organization. Coronavirus disease 2019 (COVID-19) situation report 144, 12 June 2020.

https://www.who.int/docs/default-source/coronaviruse/situationreports/20200612-covid-19-sitrep-144.pdf?sfvrsn=66ff9f4f_2

8. Guan WJ, Ni ZY, Hu Y, Liang WH, Ou CQ, He JX, et al. Clinical characteristics of coronavirus disease 2019 in China. N Engl J Med. 2020;382:1708-1720.

https://doi.org/10.1056/NEJMoa2002032

9. Zhang JJ, Dong X, Cao YY, Yuan YD, Yang YB, Yan QQ, et.al. Clinical characteristics of 140 patients infected by SARS-CoV-2 in Wuhan, China. 2020.

https://doi.org/10.1111/all.14238

10. Xu X, Chen P, Wang J, Feng J, Zhou H, Li X, et al. Evolution of the novel coronavirus from the ongoing Wuhan outbreak and modeling of its Spike protein for risk of human transmission. Sci China Life Sci. 2020;63(3):457-460. https://doi.org/10.1007/s11427-020-1637-5

11. Hoffman M, Weber HK, Schroeder S, Kruger N, Herrler T, Erichsen S, et al. SARS-CoV-2 cell entry depends on ACE2 and TMPRSS2 and is blocked by a clinically proven protease inhibitor. Cell. 2020,181(2):271-280. https://doi.org/10.1016/j.cell.2020.02.052

12. Li W, Moore MJ, Vasilieva N, Sui J, Wong SK, Berne MA, et al. Angiotensin-converting enzyme 2 is a functional receptor for the SARS coronavirus. Nature. 2003; 426:450-454. https://doi.org/10.1038/nature02145

13. Zhao $Y$, Zhao Z, Wang Y, Zhou Y, Ma $Y$ and Zuo W. Singlecell RNA expression profiling of ACE2, the putative receptor of Wuhan 2019-nCov. bioRxiv. 2020. https://doi.org/10.1101/2020.01.26.919985

14. Zhou P, Yang XL, Wang XG, Hu B, Zhang L, Zhang W, et al. A pneumonia outbreak associated with a new coronavirus of probable bat origin. Nature. 2020;579(7798):270-273. https://doi.org/10.1038/s41586-020-2012-7

15. Zhang $\mathrm{H}$, Penninger JM, Li $\mathrm{Y}$, Zhong $\mathrm{N}$ and Slutsky AS. Angiotensin-converting enzyme 2 (ACE2) as a SARS-CoV-2 receptor: molecular mechanisms and potential therapeutic target. Intensive Care Med. 2020;46(4):586-590. https://doi.org/10.1007/s00134-020-05985-9

16. Crackower MA, Sarao R, Oudit GY, Yagil C, Kozieradzki I, Scanga SE, et al. Angiotensin-converting enzyme 2 is an essential regulator of heart function. Nature. 2002;417(6891):822-828. https://doi.org/10.1038/nature00786

17. Gu J, Gong E, Zhang B, Zheng J, Gao Z, Zhong Y, et al. Multiple organ infection and the pathogenesis of SARS. J Exp Med. 2005;202(3):415-424. https://doi.org/10.1084/jem.20050828

18. Hamming I, Timens W, Bulthuis MLC, Lely AT, Navis GJ and van Goor $\mathrm{H}$. Tissue distribution of ACE2 protein, the functional receptor for SARS coronavirus: a first step in understanding 
SARS pathogenesis. J Pathol. 2004;203:631-663.

https://doi.org/10.1002/path.1570

19. Hashimoto $T$, Perlot $T$, Rehman A, Trichereau J, Ishiguro $H$, Paolino M, et al. ACE2 links amino acid malnutrition to microbial ecology and intestinal inflammation. Nature. 2012;487(7408): 477-481. https://doi.org/10.1038/nature11228

20. Zhang H, Kang Z, Gong H, Xu D, Wang J, Li Z, et al. Digestive system is a potential route of COVID-19: an analysis of singlecell coexpression pattern of key proteins in viral entry process. Gut. 2020;69:1010-1018.

https://doi.org/10.1136/gutjnl-2020-320953

21. Holshue ML, DeBolt C, Lindquist S, Lofy KH, Wiesman J, Bruce $\mathrm{H}$, et al. First Case of 2019 Novel Coronavirus in the United States. N Engl J Med. 2020;382(10):929-936. https://doi.org/10.1056/NEJMoa2001191

22. Ferrario CM, Jessup J, Chappell MC, Averill DB, Brosnihan KB, Tallant EA, et al. Effect of angiotensin-converting enzyme inhibition and angiotensin II receptor blockers on cardiac angiotensinconverting enzyme 2. Circulation. 2005;111:2605-2610. https://doi.org/10.1161/CIRCULATIONAHA.104.510461

23. Furuhashi M, Moniwa N, Mita T, Fuseya T, Ishimura S, Ohno K, et al. Urinary angiotensin-converting enzyme 2 in hypertensive patients may be increased by olmesartan, an angiotensin II receptor blocker. Am J Hypertens. 2015;28:15-21.

https://doi.org/10.1093/ajh/hpu086

24. Yang P, Gu H, Zhao Z, Wang W, Cao B, Lai C, et al. Angiotensinconverting enzyme 2 (ACE2) mediates influenza H7N9 virusinduced acute lung injury. Scientific Reports. 2015;4:7027. https://doi.org/10.1038/srep07027

25. Wan Y, Shang J, Graham R, Baric RS and Li F. Receptor recognition by novel coronavirus from Wuhan: an analysis based on decade-long structural studies of SARS coronavirus. J Virol. 2020;94:e00127-e00128.

https://doi.org/10.1128/JVI.00127-20

26. Vaduganathan $M$, Vardeny $O$, Michel T, McMurray JJV, Pfeffer MA and Solomon SD. Renin-Angiotensin-Aldosterone system inhibitors in patients with COVID-19. N Eng J Med. 2020. https://doi.org/10.1056/NEJMsr2005760

27. Guo T, Fan Y, Chen M, Wu X, Zhang L, He T, et al. Cardiovascular implications of fatal outcomes of patients with coronavirus disease 2019 (COVID-19). JAMA Cardiol 2020.

https://doi.org/10.1001/jamacardio.2020.1017

28. Sama IE, Ravera A, Santema BT, Goor HV, Maaten JMT, Cleland JGF, et al. Circulating plasma concentrations of angiotensin-converting enzyme 2 in men and women with heart failure and effects of renin-angiotensin-aldosterone inhibitors. Eur Heart J. 2020;41(19):1810-1817.

https://doi.org/10.1093/eurheartj/ehaa373

29. Campbell DJ, Zeitz CJ, Esler MD and Horowitz JD. Evidence against a major role for angiotensin-converting enzymerelated carboxypeptidase (ACE2) in angiotensin peptide metabolism in the human coronary circulation. J Hypertens 2004; 22: 1971-1976.

https://doi.org/10.1097/00004872-200410000-00020

30. Luque M, Martin P, Martell N, Brosnihan KB and Ferrario CM. Effects of captopril related to increased levels of prostacyclin and angiotensin-(1-7) in essential hypertension. J Hypertens 1996; 14: 799-805.

https://doi.org/10.1097/00004872-199606000-00017

31. Fang L, Karakiulakis $G$ and Roth $M$. Are patients with hypertension and diabetes mellitus at increased risk for COVID-19 infection?
Lancet Respir Med. 2020; 8(4):e21.

https://doi.org/10.1016/S2213-2600(20)30116-8

32. Chan PK, To KF, Lo AW, Cheung JLK, Chu I, Au FWL, et al. Persistent infection of SARS coronavirus in colonic cells in vitro. J Med Virol. 2004;74:1-7. https://doi.org/10.1002/jmv.20138

33. Imai Y, Kuba K, Rao S, Huan Y, Guo F, Guan B, et al. Angiotensinconverting enzyme 2 protects from severe acute lung failure. Nature. 2005;436:112-116. https://doi.org/10.1038/nature03712

34. Kuba K, Imai Y, Rao S, Gao H, Guo F, Guan B, et al. A crucial role of angiotensin-converting enzyme 2 (ACE2) in SARS coronavirus-induced lung injury. Nat Med. 2005;11:875-879. https://doi.org/10.1038/nm1267

35. Gurwitz D. Angiotensin receptor blockers as tentative SARSCoV-2 therapeutics. Drug Dev Res. 2020. https://doi.org/10.1002/ddr.21656

36. de Abajo FJ, Rodríguez-Martín S, Lerma V, Mejia-Abril G, Aguilar M, Garcia-Luque A, et al. Use of renin-angiotensinaldosterone system inhibitors and risk of COVID-19 requiring admission to hospital: a case-population study. Lancet. 2020;395(10238):1705-1714 https://doi.org/10.1016/S0140-6736(20)31030-8

37. Mehta N, Kalra A, Nowacki AS, Anjewierden S, Han Z, Bhat P, et al. Association of Use of Angiotensin-Converting Enzyme Inhibitors and Angiotensin II Receptor Blockers With Testing Positive for Coronavirus Disease 2019 (COVID-19). JAMA Cardiol. 2020; e201855. https://doi.org/10.1001/jamacardio.2020.1855

38. Zhang P, Zhu L, Cai J, Lei F, Qin JJ, Xie J, et al. Association of Inpatient Use of Angiotensin-Converting Enzyme Inhibitors and Angiotensin II Receptor Blockers With Mortality Among Patients With Hypertension Hospitalized With COVID-19. Circulation research. 2020; 126(12), 1671-1681. https://doi.org/10.1161/CIRCRESAHA.120.317242

39. Kuster G, Pfister O, Burkard T, Zhou Q, Twerenbold R, Haaf P, et al. SARS-CoV-2: should inhibitors of the renin-angiotensin system be withdrawn in patients with COVID-19?. Eur Heart J. 2020;0:1-3.

https://doi.org/10.1093/eurheartj/ehaa235

40. Ponikowski $\mathrm{P}$, Voors AA, Anker SD, Bueno $\mathrm{H}$, Cleland JGF, Coats AJS, et al. 2016 ESC Guidelines for the diagnosis and treatment of acute and chronic heart failure: the Task Force for the diagnosis and treatment of acute and chronic heart failure of the European Society of Cardiology (ESC) Developed with the special contribution of the Heart Failure Association (HFA) of the ESC. Eur Heart J. 2016;37:2129-2200. https://doi.org/10.1093/eurheartj/ehw128

41. Williams B, Mancia G, Spiering W, Rosei EA, Azizi M, Burnier M, et al. $2018 \mathrm{ESC} / \mathrm{ESH}$ Guidelines for the management of arterial hypertension. Eur Heart J. 2018;39:3021-3104. https://doi.org/10.1093/eurheartj/ehy339

42. Ibanez B, James S, Agewall S, Antunes MJ, Bucciarelli-Ducci C, Bueno H, et al. 2017 ESC Guidelines for the management of acute myocardial infarction in patients presenting with STsegment elevation: the Task Force for the management of acute myocardial infarction in patients presenting with ST-segment elevation of the European Society of Cardiology (ESC). Eur Heart J. 2018;39:119-177. https://doi.org/10.1093/eurheartj/ehx393

43. ESC Council on Hypertension. Position Statement of the ESC Council on Hypertension on ACE-Inhibitors and Angiotensin Receptor Blockers. 2020. 
https://www.escardio.org/Councils/Council-on-Hypertension$(\mathrm{CHT}) / \mathrm{News} /$ position-statement-of-the-esc-council-onhypertension-on-ace-inhibitors-and-ang

44. American College of Cardiology. HFSA/ACC/AHA Statement Addresses Concerns Re: Using RAAS Antagonists in COVID-19. 2020.

https://www.acc.org/latest-in-cardiology/articles/2020/03/17/08/59/ hfsa-acc-aha-statement-addresses-concerns-re-using-raasantagonists-in-covid-19

45. Yang X, Yu Y, Xu J, Shu H, Xia J, Liu H, et. al. Clinical course and outcomes of critically ill patients with SARS-CoV-2 pneumonia in Wuhan, China: a single-centered, retrospective, observational study. Lancet Respir Med. 2020;8(5):475-481.

https://doi.org/10.1016/S2213-2600(20)30079-5

\section{Author's Contributions:}

TIH-Conceptualized and designed the study, literature search, prepared first draft of the manuscript, critical revision of the manuscript; KV- Conceptualized the study, literature search, prepared first draft of the manuscript, review of the study; VD-Conceptualized the study, Interpretation, Literature search, critical revision of the manuscript; FK- Conceptualized the study, literature search, critical revision of the manuscript; NLS-Conceptualized the study, literature search, prepared the first draft of the manuscript; AK-Conceptualized the study, review of the study, critical revision of the manuscript.

Running title: The Use of ACE inhibitor/ARB in SARS-CoV-2 Patients

Work Attributed to:

Faculty of Medicine, Pelita Harapan University and Mochtar Riady Institute of Nanotechnology

Orcid ID:

Dr. Timotius Ivan Hariyanto - (10) https://orcid.org/0000-0002-1748-9776

Dr. Andree Kurniawan - (1) https://orcid.org/0000-0002-5219-9029

Source of funding: None, Conflict of interest:The authors declare that the study was conducted in the absence of any commercial or financial relationship that could pose as a potential conflict of interest. 